\title{
Peptide vaccines for hematological malignancies: a missed promise?
}

\author{
Monica Bocchia $\cdot$ Marzia Defina $\cdot$ Lara Aprile • \\ Anna Sicuranza
}

Received: 3 December 2013/ Accepted: 20 December 2013/Published online: 8 January 2014

(C) The Japanese Society of Hematology 2014

\begin{abstract}
Despite the crucial aid that newly developed target therapies are providing to chemotherapy and stem cell transplant, the cure for many hematological malignancies is still an unmet need. Although available therapies are able to induce an effective debulking of the tumor, most of the time, an insidious minimal residual disease survives current treatments and it is responsible for an immediate or delayed relapse. Peptide-derived antitumor vaccines have been developed with the idea that an artificially "educated" immune system may exert an active specific antitumor response able to control and ultimately eradicate underlying post-treatment residual disease. This review will summarize current knowledge of peptide vaccines for hematological malignancies, trying to analyze promises and pitfalls of a safe and intelligent tool that after many years from its first appearance has not yet established its potential role as alternative immune mediated therapeutic approach for hematopoietic tumors.
\end{abstract}

Keywords Peptide vaccines - Immunotherapy ·

Antigens $\cdot$ Leukemia $\cdot$ Hematological malignancies

\section{Introduction}

Despite recent advances in the treatment of hematological malignancies such as the more effective combination chemotherapy, the use of targeted therapy and the major impact conferred by bone marrow transplantation, many

M. Bocchia $(\bowtie) \cdot$ M. Defina · L. Aprile · A. Sicuranza Department of Hematology, University of Siena, Azienda Ospedaliera Universitaria Senese, Viale Bracci 16, 53100 Siena, Italy

e-mail: bocchia@unisi.it patients will relapse and die of their disease. One promising alternative approach for targeting hematological malignancies involves the immune system; in fact, a growing body of evidence suggests that cellular immunemediated mechanisms may aid in the killing of malignant cells in patients with hematological diseases. The main efficacy of cellular immunity in this setting has been supported by the finding that allogeneic transplantation is curative for a subset of patients with leukemia, lymphoma and multiple myeloma. The primary mechanism is the "graft-versus-leukemia effect" in which alloreactive effector cells eliminate post-transplant residual disease [13]. However, the lack of specificity of this immune response results in the concurrent risk of "graft-versushost-disease". To reduce the damage to normal tissues, an active immune approach should be based on a cancer vaccine that educates host immunity to selectively target malignant cells. Among all possible types of antitumor vaccines, peptide vaccines are by far the easiest to develop: usually they are tumor specific but not patients specific, they are simple and cheap to produce even in large scale and they are easy to administer to patients. Two major obstacles in developing anticancer vaccine and particularly peptide vaccines are (i) identifying appropriate antigens to target and (ii) generating immune responses against tumor antigens to which the immune system has been already exposed and thus rendered "tolerant" or unresponsive.

\section{Tumor-associated antigens}

A rational development of cancer vaccines depends on the molecular definition of tumor-associated antigens that can be injected into cancer patients to induce a systemic immune response that may result in the destruction of the 
cancer growing [4]. Since the identification of MAGE-1, the first gene reported to encode a human tumor antigen recognized by $\mathrm{T}$ cells [5], a large number of tumor antigens have been described. Initial classification was based on expression profiles, with tumor-specific antigens (TSAs) being expressed only by cancer cells and tumor-associated antigens (TAAs) representing the mutated counterpart of proteins expressed by normal tissues. The currently accepted classification includes only TAAs, which are divided into shared and unique TAAs and further classified into class I and class II HLA-restricted TAAs, according to the HLA allele restriction [6].

Among shared TAAs, three groups can be identified: (i) cancer testis (CT) antigens, (ii) differentiation antigens, and (iii) overexpressed antigens. The first ones are expressed in histologically different human tumors and, among normal tissues, in spermatocytes/spermatogonia of testis and occasionally in placenta. CT antigens, such as MAGE-1, result from the reactivation of genes which are normally silent in adult tissue, but are activated in different tumor [7]. Differentiation antigens are expressed by the normal tissue from which the tumor arose (i.e., Gp100, PSA, CEA) and are considered "self-antigens". Overexpressed antigens have been detected in different types of tumors as well as in many normal tissues and their overexpression in tumor cells can reach the threshold for $\mathrm{T}$ cell recognition, breaking the immunological tolerance.

Considering shared TAAs, most of the advances have occurred in the field of solid malignancies, even if, the presence of these TAAs in hematological disease has been documented. In fact, van Baren et al. [8] have found that genes encoding some CT antigens (MAGE, BAGE, LAGE and GAGE) are expressed in a high proportion of patients with advanced stage multiple myeloma, while PRAME antigens is selectively expressed in $47 \%$ of acute myeloid leukemia patients [9].

In the field of overexpressed antigens, 3 candidates have been described as markedly overexpressed in different types of hematological malignancies: the proteinase-3 (PR3), Wilm's tumor gene-encoded transcription factor-1 (WT-1) and mucin-1 (MUC-1). The PR-3, a primary neutrophilic protein, is overexpressed in leukemic progenitors from patients with acute myeloid leukemia (AML) and chronic myeloid leukemia (CML), but is minimally expressed by normal marrow progenitors [10]. The WT-1 is a zinc finger transcription factor involved in leukemogenesis and is also overexpressed in different types of leukemia [11], while the MUC-1, an immunogenic epithelial mucin present in an underglycosylate form on solid tumor, has also been found to be overexpressed in multiple myeloma [12].

Unique TAAs are products of random somatic point mutations induced by carcinogenesis and therefore expressed uniquely by individual tumors and not by any normal tissue, representing the only true tumor-specific antigens. A relevant feature of this type of antigens is their potential resistance to immunoselection if the mutated protein is crucial to the oncogenic process and thus indispensable for maintaining the neoplastic state. As a consequence, unique TAAs should elicit an immune response clinically more effective than that of shared antigens.

Unlike for the solid tumor in which the identification of unique tumor antigens requires sequencing of the whole genome of each individual tumor, the strategy is relatively easy and feasible for hematological diseases. In fact, a common finding in these malignancies, especially in leukemia, is the presence of chromosomal translocations that result in the generation of fusion genes encoding chimeric proteins that are unique of the tumor cells. The first joining region of these chimeric proteins to be evaluated as true tumor-specific antigen has been BCR-ABL protein [13], but many other fusion gene products such as PML-RARa, AML1-ETO, DEK-CAN are appealing targets for immunotherapy [14].

Another hypothetical target is the idiotype in B cell lymphoma and multiple myeloma that represents clonal expansions of lymphoid cells with rearranged immunoglobulin genes. The V-D-J recombination sequence results in a unique hypervariable region characteristic of each individual tumor. This sequence is known as idiotype (Id) and represents a tumor-specific antigen that has been used as a target for an active immunization with a patient-specific Id vaccine $[15,16]$. Once a tumor antigen has been identified, another critical issue is to choose the proper peptide sequence and the ideal peptide length potentially able to be processed and presented by antigen-presenting cells (APCs) to effector T cells [17] (Fig. 1).

\section{Strategies of vaccination}

Immune tolerance of tumor antigens

The ability of cancer-derived peptide vaccine to elicit an immune response to cancers has been well documented in several clinical trials; however, effective antitumor immune responses are hampered by the weak immunogenicity of tumor antigens and their derived peptides. In fact, the immune system of the patients with a cancer fails to control tumor growth because it may have been rendered "tolerant or unresponsive" to the tumor. Several strategies have been adopted to overcome these limitations and to increase the immunogenicity of tumor antigens-derived peptides, including the introduction of inflammatory cytokines in the vaccination protocols, such as alpha interferon (IFN- $\alpha$ ) [18] and interleukin-2 (IL-2) [19], or through the 
Fig. 1 Processing and presentation of peptides and ultimately of peptide vaccines to $\mathrm{T}$ cellular immune system. (modified from NCI Cancer Bulletin. 2010;7:9)

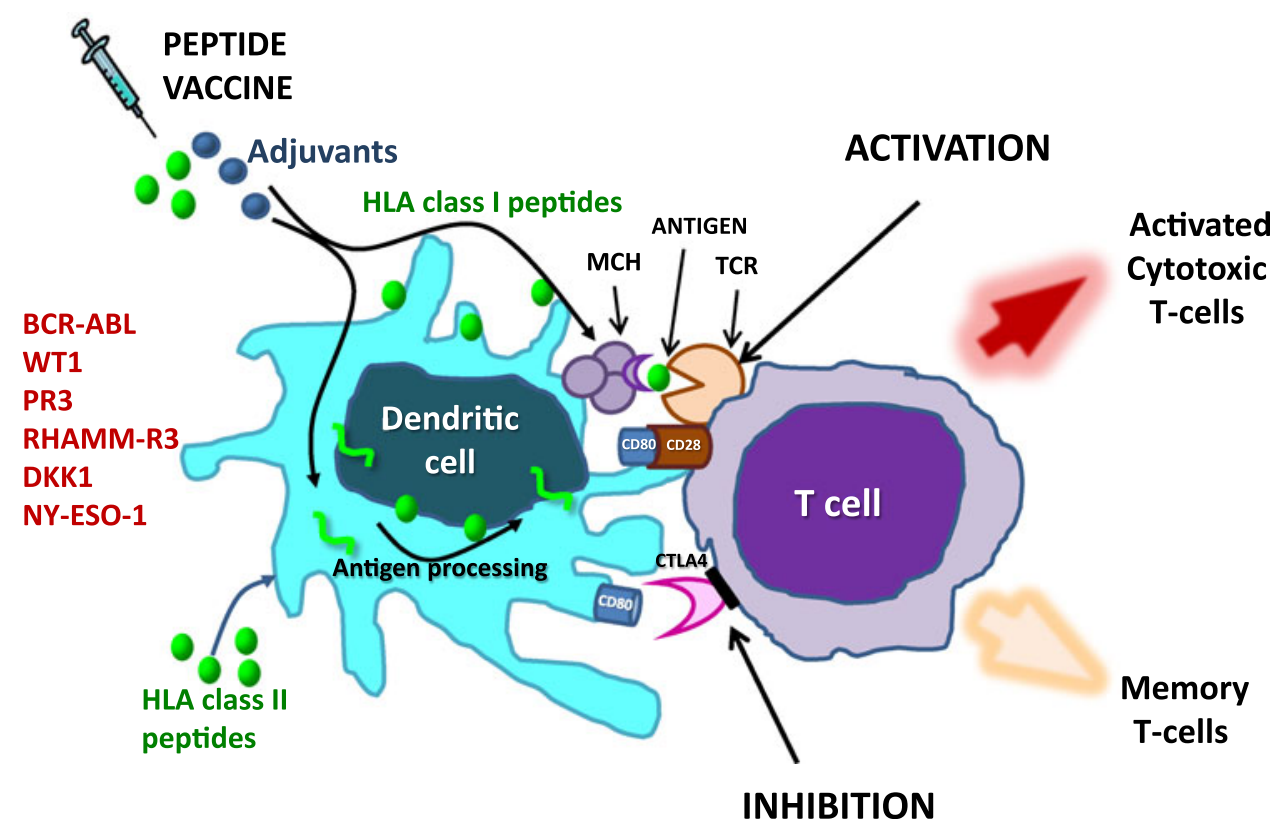

generation of peptide variants of TAAs, including heteroclitic peptides and altered-peptide ligands [20], but the overall results of these clinical trials are controversial. Significant improvement in the immunogenicity of peptide vaccines has been achieved using long peptide versus short peptides; in fact, the last ones may bind directly to MHC molecules on cells that are not professional APCs, thereby potentially inducing tolerance or anergy [21]. In contrast, recent works with long (30-mer) peptides that encompass short minimal epitopes suggest that these longer peptides may be more effective immunogens than the minimal peptides because they are too long to be presented directly on MHC, so they must be internalized by professional APCs and processed for presentation [22]. In addition, unlike short peptides, long peptides induce memory CD8+ $\mathrm{T}$ cell responses that are boosted dramatically on repeated vaccination in mice, and induce substantially improved tumor control compared to vaccinations with short peptides [23]. The employment of these long peptides promises to induce a broad a more durable adaptive immune responses against multiple antigens. Another way to explain the immune tolerance to cancer is the limited cytotoxic $\mathrm{T}$ lymphocyte (CTL) expansion due to activation of regulatory $\mathrm{T}$ lymphocytes [24]. In fact, T-reg cells have been found to be increased in peripheral blood and tumors in a variety of human cancers [25], resulting in poorer prognosis and reduced survival [26]. The presence of circulating T-reg cells may, indeed, represent a major obstacle to the success of cancer vaccines; therefore, an alternative strategy to improve the efficacy of tumor vaccines could be their combination with therapeutic intervention aimed at eliminating or controlling $\mathrm{CD} 4+\mathrm{CD} 25+$ regulatory $\mathrm{T}$ cells. On this regard, many approaches have been explored in preclinical and clinical studies; the first one is the use, as pre-treatment, of cytostatic drugs (i.e., cyclophosphamide) with the intent to improve the immune response to cancer vaccines in humans [27]. Other strategies of T-reg cells control are the use of a recombinant IL-2 diphtheria toxin conjugate [28] or the use of an anti-CD25 monoclonal antibody [29].

Immunological adjuvants

Due to their weak immunogenicity, the tumor-specific peptide vaccines are usually associated with immunological adjuvants that have many critical functions including activation of innate immunity, optimization of antigen presentation, recruitment of APCs to the vaccine site and creating a cytokine environment that supports the immunologic outcome [30].

In the field of hematological malignancies, the most common immunological adjuvant used as active immune stimulating agent is the granulocyte-macrophage colonystimulating factor (GM-CSF). This cytokine was administered either as product of gene-transduced tumor cells or as recombinant protein together with the vaccine (mainly a peptide vaccine) given subcutaneously or intradermally. The results of these trials were heterogeneous in terms of induction of vaccine-specific immune response and of clinical response. Though in some of these studies GMCSF appeared to help in generating an immune response, in others no effect or even a suppressive effect was reported [31, 32]. On this regard, a recent review has been published in which the authors concluded that GM-CSF may increase the vaccine-induced immune response when administered repeatedly at relatively low doses (range 40-80 $\mu \mathrm{g}$ for 
1-5 days), whereas an opposite effect was often reported at dosages of 100-500 $\mu \mathrm{g}$ [33]. The potential mechanism of the GM-CSF-mediated immune suppression could reside in the expansion of myeloid suppressor cells by endogenous tumor-derived or exogenous GM-CSF.

Peptide vaccines in acute myeloid leukemia and myelodysplastic syndrome

Up to date, differently from other hematological diseases, in AML and MDS fewer progresses have been obtained in terms of new drugs and novel therapeutic approaches with hematopoietic stem cells transplantation (HSCT) being the most reliable curative strategy. Unfortunately, many patients are not candidates for this option, and however, relapse rate is still high as well as transplant-related mortality. In AML, the key issue is minimal residual disease persisting after conventional chemotherapy and even after allogeneic SCT, and innovative therapeutic approaches to attempt to eradicate residual leukemic cells are required. In this context, one promising option could be an active specific immune strategy with leukemia-derived peptide vaccines. A similar immunotherapeutic approach is more challenging in MDS as the immune system plays an important role both in early disease development and during progression to advanced stages. In fact, the presence of autoimmune disease-like features is widely recognized in the physiopathology of early MDS, whereas advanced MDS is characterized by immune evasion [34].

Based on these premises, different studies have identified several leukemia-associated antigens (LAAs) and tested different peptide vaccination strategies with the intent to induce in vivo anti-leukemic response in AML and MDS patients. Main characteristics and clinical results of the most recent peptide vaccination studies are summarized in Table 1 [35-42].

One of the most suitable potentially immunogenic targets, overexpressed in AML and MDS, is WT1 protein [43, 44]. Preliminary results of a phase I study on AML, MDS, lung and breast cancer patients published by Oka et al. in 2004 [37] showing the ability of WT1 peptide vaccine to induce an immunological response, were more recently confirmed by Keilholz's group [38] and by Memorial Sloan Kettering Cancer Center [39] in AML and MDS patients. On the basis of previous results, a phase II study with increased frequency of vaccination (twice a week) combining PR1- and WT1-derived peptides was planned by Rezvani et al. [42] with the intent to enhance the degree and duration of immune response. The 6 patients enrolled showed either a PR1- or WT1-specific T cell response, but repeated vaccinations did not lead to a significant reduction of WT1 expression level and consequently of residual

Table 1 Peptide vaccine clinical trials in AML, MDS and other malignancies

\begin{tabular}{|c|c|c|c|c|c|}
\hline Study & No of patients & Antigen & $\begin{array}{l}\text { HLA } \\
\text { type }\end{array}$ & Adjiuv. & Response \\
\hline $\begin{array}{l}\text { Oka et al. } \\
\text { [37] }\end{array}$ & $\begin{array}{l}26 \text { patients (AML, } \\
\text { MDS, breast and lung } \\
\text { cancer) }\end{array}$ & WT1 & HLA-A2 & ISA-51 & $\begin{array}{l}20 \text { patients showed clinical responses such as reduction in leukemic } \\
\text { blast cells or tumor sizes and/or tumor markers }\end{array}$ \\
\hline $\begin{array}{l}\text { Qazilbash } \\
\text { et al. } \\
\text { [35] }\end{array}$ & $\begin{array}{l}66 \text { patients (AML, } \\
\text { CML, MDS) }\end{array}$ & PR1 & HLA-A2 & $\begin{array}{l}\text { ISA-51 } \\
\text { GM-CSF }\end{array}$ & $\begin{array}{l}53 \text { patients with measurable disease; } 25 / 53 \text { patients with PR1 } \\
\text { specific immune response. Clinical responses in } 9 / 25 \text { immune } \\
\text { responders vs } 3 / 28 \text { immune non-responders }\end{array}$ \\
\hline $\begin{array}{l}\text { Rezvani } \\
\text { et al. } \\
\text { [41] }\end{array}$ & $\begin{array}{l}8 \text { patients (AML, MDS, } \\
\text { CML) }\end{array}$ & WT1 PR1 & HLA-A2 & $\begin{array}{l}\text { ISA-51 } \\
\text { GM-CSF }\end{array}$ & $\begin{array}{l}\mathrm{PR} 1 \text { or } \mathrm{WT} 1^{+} \mathrm{CD} 8^{+} \mathrm{T} \text { cells associated with a decrease in WT1 } \\
\text { mRNA expression as a marker of minimal residual disease. Loss of } \\
\text { response associated with reappearance of WT1 transcripts }\end{array}$ \\
\hline $\begin{array}{l}\text { Keilhouz } \\
\text { et al. } \\
\text { [38] }\end{array}$ & $\begin{array}{l}17 \text { AML patients, } 2 \\
\text { MDS patients }\end{array}$ & WT1 & HLA-A2 & $\begin{array}{l}\text { GM-CSF } \\
\text { KLH }\end{array}$ & $\begin{array}{l}10 \text { AML patients in SD; } 4 \text { patients had clinical benefit after initial } \\
\text { progression (1CR, } 2 \mathrm{SD}) \text {. Reduction of WT1 transcript in } 35 \% \text { of } \\
\text { patients }\end{array}$ \\
\hline $\begin{array}{l}\text { Greiner } \\
\text { et al. } \\
{[36]}\end{array}$ & $\begin{array}{l}9 \text { patients (AML, MDS, } \\
\text { MM) }\end{array}$ & $\begin{array}{l}\text { RHAMM- } \\
\text { R3 }\end{array}$ & HLA-A2 & ISA-51 & $\begin{array}{l}4 \text { patients with positive immunological responses, } 3 \text { patients with } \\
\text { positive clinical effects }\end{array}$ \\
\hline $\begin{array}{l}\text { Maslak } \\
\text { et al. } \\
\text { [39] }\end{array}$ & 10 AML patients & WT1 & $\begin{array}{l}\text { HLA- } \\
\text { A2/DR }\end{array}$ & GM-CSF & $\begin{array}{l}9 \text { Evaluable patients; WT1 specific T cell response but reduced } \\
\text { follow-up }\end{array}$ \\
\hline $\begin{array}{l}\text { Sugiyama } \\
\text { et al. } \\
{[40]}\end{array}$ & 12 AML patients & WT1 & HLA-A2 & ISA-51 & $\begin{array}{l}4 \text { patients stable } \mathrm{CR} ; 8 \text { patients reduction molecular minimal residual } \\
\text { disease }\end{array}$ \\
\hline $\begin{array}{l}\text { Rezvani } \\
\text { et al. } \\
\text { [42] }\end{array}$ & $\begin{array}{l}8 \text { patients (phase II } \\
\text { study) }\end{array}$ & WT1 PR1 & HLA-A2 & $\begin{array}{l}\text { ISA-51 } \\
\text { GM-CSF }\end{array}$ & $\begin{array}{l}\text { Repeated delivery of peptides with Montanide-adjuvant and GM- } \\
\text { CSF leads to rapid loss of high-avidity peptide-specific CD8(+) T } \\
\text { cells }\end{array}$ \\
\hline
\end{tabular}

$C R$ complete response, $S D$ stable disease 
leukemic disease. As stated by the authors, a possible cause of transient clinical responses observed in these studies could be the lack of activation of $\mathrm{CD} 4+\mathrm{T}$ pathway using HLA class I peptide vaccines that stimulate only a CD8+ T response. Indeed, $\mathrm{CD} 4+\mathrm{T}$ helpers are not necessary for the primary expansion and differentiation of $\mathrm{CD} 8+\mathrm{T}$ cytotoxic effectors, but they are necessary for the secondary expansion of the CD8+ $\mathrm{T}$ cytotoxic effectors [41, 42]. However, in all patients responding after WT1 peptidederived vaccination, Ochsenreither's group characterized a predominant $\mathrm{V} \beta \mathrm{T}$ cell receptor (TCR) clone, presumably a mediator of the clinical response [45]. For acute promyelocytic leukemia, despite PML-RAR $\alpha$ fusion protein is a proper leukemia-specific antigen, just few DNA vaccine studies in animal models were performed [46].

In conclusion, the clinical results of peptide vaccine trials in AML and MDS are promising but still not satisfactory as in few cases a reduction of antigen target expression or the improvement of blasts counts of peripheral blood or bone marrow was observed, while more often antitumor peptide vaccinations were followed by the detection of an immunological response to the peptide without a clinical improvement.

\section{Peptide vaccines in chronic myeloid leukemia}

Chronic myelogenous leukemia (CML) is considered particularly suitable for an immunotherapeutic approach. Despite the success of tyrosine kinase inhibitors (TKIs), the persistence of CD34+ leukemia precursors during TKIs [47] and the need of a life-time treatment, renovated the interest in a potential immune-mediated control of this disease. The presence of a unique BCR-ABL fusion protein, due to the reciprocal $t(9 ; 22)$ translocation is considered an ideal target for an immunological attack to leukemic cells. The capacity of BCR-ABL breakpointderived peptides to bind to HLA molecules and to elicit a peptide-specific $\mathrm{T}$ cell response [13, 48] supported the development of a peptide vaccine strategy and the evidence that CML leukemic cells present breakpoint peptides on the cell surface within the HLA molecules reinforced the idea that peptide vaccinations may win mechanisms of immunological tolerance which allow the growth and survival of leukemic clone [49]. The more important BCR-ABL peptide vaccine studies, developed during the years, are summarized in Table 2 [50-55]. Within these studies, an interesting approach to increase peptide immunogenicity was made by Scheinberg et al. using modified synthetic BCR-ABL-derived breakpoint peptides (so-called heteroclitic peptides) able to bind with higher affinity to HLA class I molecules and TCR yet maintaining the specificity of the antitumor immune response [54]. Even if a peptidespecific immune response induced by vaccinations was demonstrated in most of these studies, as well as a reduction in BCR-ABL transcript, a clear clinical benefit for vaccinated CML patients was not demonstrated. To try to answer to this question, we conducted a multicenter CML peptide vaccine using 5 b3a2-derived breakpoint peptides in combination with GM-CSF in $68 \mathrm{CML}$ patients with persistent molecular disease after long lasting imatinib treatment. An interim analysis of the study showed that peptide vaccinations were able to reduce residual BCRABL transcript in about $50 \%$ of patients [56]. We are completing the study core of 4 years (inclusive of 3 years of maintenance of vaccine treatment every 6 months) for all patients, and data will be soon ready for final publication. Actual patients' follow-up reached a median of 9 years from starting imatinib, and about $80 \%$ of patients are still on treatment despite the presence of fluctuating BCR-ABL transcript (about $12 \%$ of patients lost sporadically MMR without shifting to another TKI); on the contrary, $15 \%$ of patients showed a persistent increase of molecular disease and switched to second generation TKIs. If we consider that in the IRIS 8 years update report only $55 \%$ of patients are still on imatinib [57], our data may suggest that CML peptide vaccine could favor a stable response to imatinib allowing patients to "tolerate" higher level of BCR-ABL transcript without the need to switch to alternative TKIs. Other tumor-associated antigens, not CML specifics, such as PR3 and WT1, were studied for the presence of immunogenic peptides. Rezvani et al. published the results of combined vaccination with HLA-A2specific peptides derived from WT1 and Proteinase 3 in 8 patients with myeloid malignancies. In all of them, an immune response was recorded and 3 out of 8 patients showed decreased or complete eradication of WT1 mRNA [41].

More recently, Brossart's team has brought an important twist in the tale and has dramatically changed the prevailing concept [58]. They demonstrated that the presence of p210 in CML cells is critic for the expression of the antigens, although it is not the major immunogenic antigen of CML cells. Based on these premises, different approaches to elicit an effective immune response against CML cells may be on the way [59].

\section{Peptide vaccines in multiple myeloma}

In spite of recent discoveries, multiple myeloma (MM) remains an incurable disease in the vast majority of patients. The relapse is the principal cause of treatment failure, due to the persistence of clonogenic plasma cells in the bone marrow after current available therapy. In MM, the therapeutic benefit of allo-SCT mediated by the immune effect of donor-derived $\mathrm{T}$ cells, has supported the development of alternative immunotherapeutic approach 
Table 2 Peptide vaccine clinical trials in CML

\begin{tabular}{|c|c|c|c|c|c|}
\hline Study & No of patients & Antigen & HLA type & Adjiuv. & Response \\
\hline $\begin{array}{l}\text { Pinilla- } \\
\text { Ibarz } \\
\text { et al. [50] }\end{array}$ & $\begin{array}{l}12 \text { patients treated with } \\
\text { INF } \alpha \text {, chronic phase }\end{array}$ & BCR-ABL & Any & QS-21 & $\begin{array}{l}\text { In } 3 \text { of the } 6 \text { patients treated at the } 2 \text { highest dose levels of } \\
\text { vaccine, peptide-specific, T cell proliferative responses } \\
(n=3) \text { and/or DTH responses }(n=2) \text { were observed. } \\
\text { Cytotoxic T lymphocytes have not been identified }\end{array}$ \\
\hline $\begin{array}{l}\text { Cathcart } \\
\text { et al. [51] }\end{array}$ & $\begin{array}{l}14 \text { patients treated with } \\
\text { imatinib, INF } \alpha \text { (phase } \\
\text { II trial) }\end{array}$ & BCR-ABL & Any & QS-21 & $\begin{array}{l}11 \text { patients showed IFN-y release by ELISPOT at one or more } \\
\text { time points. A peptide-specific CD8(+)IFN-y ELISPOT was } \\
\text { found in } 4 \text { patients; } 3 \text { patients with PCR negative after } \\
\text { vaccination;5 patients on INF-a treatment in CCyR }\end{array}$ \\
\hline $\begin{array}{l}\text { Bocchia } \\
\text { et al. [52] }\end{array}$ & $\begin{array}{l}16 \text { patients treated with } \\
\text { imatinib, INF } \alpha\end{array}$ & BCR-ABL & $\begin{array}{l}\text { HLA- A3/ } \\
\text { A11/B8/ } \\
\text { DR11/DR1/ } \\
\text { D }\end{array}$ & $\begin{array}{l}\text { QS-21 } \\
\text { GM- } \\
\text { CSF } \\
\text { R4 }\end{array}$ & $\begin{array}{l}\text { All patients' cytogenetic responses improved after } 6 \\
\text { vaccinations, with } 5 \text { reaching CCyR. } 3 \text { of } 5 \text { patients had } \\
\text { undetectable amounts of b3a } 2 \text { transcript. } 6 \text { patients on INF- } \alpha \\
\text { treatment with a median of } 17 \text { months' stable residual } \\
\text { disease were also vaccinated. All but one had improved } \\
\text { cytogenetic responses, and } 2 \text { reached CCyR }\end{array}$ \\
\hline $\begin{array}{l}\text { Rojas et al. } \\
\text { [53] }\end{array}$ & $\begin{array}{l}19 \text { patients treated with } \\
\text { imatinib, chronic } \\
\text { phase }\end{array}$ & BCR-ABL & HLA-A3/B8 & PADRE & $\begin{array}{l}14 \text { patients with T cell responses to BCR-ABL peptides. No } \\
\text { molecular benefit in the } 5 \text { patients not in MCyR at baseline. } \\
13 \text { patients in MCyR at baseline, developed at least } 1 \text { log fall } \\
\text { in BCR-ABL transcripts }\end{array}$ \\
\hline $\begin{array}{l}\text { Maslak } \\
\text { et al. [54] }\end{array}$ & $\begin{array}{l}13 \text { patients in CCR } \\
\text { treated with imatinib }\end{array}$ & BCR-ABL & Any & $\begin{array}{l}\text { GM- } \\
\text { CSF }\end{array}$ & $\begin{array}{l}6 \text { patients HLA-A0201 (three each with each breakpoint) and } \\
\text { one patient HLA-A0205 with b3a2, responded to the A0201 } \\
\text { analog peptide after } 5 \text { vaccinations. } 4 \text { patients HLA-A0201 } \\
\text { responded to a native peptide sequence after stimulation } \\
\text { in vitro with heteroclitic peptide or to native peptide as a } \\
\text { stimulus. }\end{array}$ \\
\hline $\begin{array}{l}\text { Jain et al. } \\
\text { [55] }\end{array}$ & $\begin{array}{l}10 \text { patients treated with } \\
\text { imatinib }\end{array}$ & BCR-ABL & Any & $\begin{array}{l}\text { ISA } 51 \\
\text { GM- } \\
\text { CSF }\end{array}$ & $\begin{array}{l}3 \text { patients achieved } 1-\log \text { reduction in BCR-ABL transcript } \\
\text { level, } 3 \text { patients with major molecular response }\end{array}$ \\
\hline
\end{tabular}

$C C y R$ complete cytogenetic response, $M C y R$ major cytogenetic response

Table 3 Vaccine clinical trials in MM

\begin{tabular}{|c|c|c|c|c|c|}
\hline Study & No of patients & Antigen & $\begin{array}{l}\text { HLA } \\
\text { type }\end{array}$ & Adjiuv. & Response \\
\hline $\begin{array}{l}\text { Osterborg } \\
\text { et al. [62] }\end{array}$ & 5 patients & Id & Any & GM-CSF & $\begin{array}{l}\text { All patients developed an Id-specific T cell immunity, defined as } \\
\text { blood T cells predominantly secreting INF- } \gamma \text { and IL-2. A } \\
\text { transient rise of B cells producing IgM anti-idiotypic } \\
\text { antibodies in all patients }\end{array}$ \\
\hline $\begin{array}{r}\text { Rassmussen } \\
\text { et al. [63] }\end{array}$ & 6 patients & Id & Any & $\begin{array}{l}\text { GM-CSF } \\
\text { IL-12 }\end{array}$ & $\begin{array}{l}4 \text { patients with reduction of blood tumor mass, with one patient } \\
\text { achieving a complete molecular remission in blood; } 3 \text { of these } \\
4 \text { patients with Id-specific T-cell response }\end{array}$ \\
\hline $\begin{array}{l}\text { Coscia et al. } \\
\text { [64] }\end{array}$ & $\begin{array}{l}15 \text { patients in first } \\
\text { remission after high- } \\
\text { dose chemotherapy }\end{array}$ & Id & Any & $\begin{array}{l}\text { KLH } \\
\text { GM-CSF }\end{array}$ & $\begin{array}{l}\text { The vaccine induced immune responses that lasted almost } \\
2 \text { years after the end of treatment. Id-specific delayed type } \\
\text { hypersensitivity skin tests were positive in } 85 \% \text { of tested } \\
\text { patients }\end{array}$ \\
\hline $\begin{array}{l}\text { Kuball et al. } \\
\text { [67] }\end{array}$ & $\begin{array}{l}5 \text { MM patients, } 4 \text { AML } \\
\text { patients }\end{array}$ & $\begin{array}{l}\text { WT1, PR3, } \\
\text { MUC1, } \\
\text { PADRE }\end{array}$ & $\begin{array}{l}\text { HLA- } \\
\text { A2/ } \\
\text { DR }\end{array}$ & $\begin{array}{l}\text { ISA-51 } \\
\text { CpG7909 }\end{array}$ & $\begin{array}{l}\text { No clinical response; only a PADRE-specific CD4+ T helper } \\
\text { cells was observed after vaccination but these appeared unable } \\
\text { to produce IL2, and CD } 4+\mathrm{T} \text { cells with a regulatory } \\
\text { phenotype increased }\end{array}$ \\
\hline
\end{tabular}

[60]. After the identification of low frequency Id-specific T cells in about $90 \%$ of patients with MM or MGUS [61], several vaccination trials employing Id-derived protein (but no Id-derived peptides) were performed often inducing a satisfactory Id-specific immune response, but a limited clinical effect (Table 3) [62-64]. Recently, to enhance the therapeutic index of allo-SCT, Foglietta et al. immunized 10 HLA-matched sibling donors before stem cell collection with recipient-derived clonal myeloma Id, as a tumor antigen, conjugated with KLH. After treatment, 8 myeloma recipients had persistent Id-specific immune responses and 5 had improvement in disease status demonstrating that 
tumor antigen-specific humoral and cellular immunity could be safely induced in allo-SCT donors and transferred to recipients [65].

Id protein is not the only myeloma-specific antigen that can be targeted by the immune system, a variety of tumorassociated antigens have been identified in myeloma cells. Among the most studied, there are NY-ESO-1 (cancer testis antigen) [66], RHAMM-R3 (receptor for hyaluronic acid-mediated motility) [36], WT1 and MUC1 (see Table 3) [69] and DKK1 (Dickkopf-1 a Wnt/Bcatenin signaling inhibitor protein) [68]. NY-ESO-1 specific CTLs generated from MM patients were shown to kill primary myeloma cells, and a clinical trial evaluating the efficacy of a vaccination strategy targeting NY-ESO-1 in association with GM-CSF is underway. Recent studies have shown that DKK1 is highly expressed in almost all MM patients and absent in normal tissues except placenta and mesenchymal stem cells and it could be a peculiar target in a vaccine strategy. However, no clinical studies employing DKK1derived peptides have been performed so far. Recently, in syngenic hematopoietic stem cell transplant setting in which donor immune responses should exclusively target unique tumor epitopes, 6 new myeloma-specific antigens were discovered, although their immunological and clinical value has not been assessed yet [69]. Kang et al. have identified two novel HLA-A2 restricted antigens derived by HLA-DOB exclusively expressed in B lineage cells and in thymic medullary epithelium, which were naturally processed and presented on MM cells. Future studies will be required to investigate a clinical utility of this epitope [70].

Peptide vaccines in chronic lymphocytic leukemia

Chronic lymphocytic leukemia (CLL) should represent an ideal model to induce immune-mediated responses, because the disease originates by antigen-presenting cells (APC) and it expresses specific tumor antigens. Yet it is difficult to elicit an immune response against CLL cells, because of the absence of co-stimulatory molecules on APCs and the high expression of immunosuppressive factors. A vaccine strategy should try to overcome this problem, making APCs more efficient in presenting antigens and in inducing an antitumor response. Even in CLL patients, peptide vaccinations with HLA-A2 specific RHAMM-R3 peptide were carried out, as in other diseases. A total of 6 HLA-A2 patients were immunized every 2 weeks with the addition of GM-CSF and in 4 patients hematological improvements such as B lymphocytes reduction in peripheral blood were observed. Five out of 6 patients showed RHAMM-R3 specific CD8+ T cells together with substantial changes in $\mathrm{T}$ cell subset and in cytokines secretion induced by vaccinations [71]. To escape the immunological defect of CLL immune system, an effective vaccine strategy should probably include the use of dendritic cells and APCs as cellular vehicle of antigens, but this is not a topic discussed in this review.

Peptide vaccines in non-hodgkin lymphoma

Several clinical investigations in lymphoma immunotherapy were performed over the years. However, the most appealing vaccines developed for non-hodgkin lymphoma, and in general for all lymphoproliferative disorders, employed tumor-derived Id protein, and not Id-derived peptides, as tumor-specific antigen. Id has been associated to immunological adjuvants like KLH or GM-CSF, to increase its immunogenic capacity [72]. Interesting studies in the recent years, are three randomized clinical trials that compared chemotherapy followed by Id vaccination to chemotherapy alone. A total of nearly 800 patients with follicular lymphoma, either previously untreated or with relapsed disease were enrolled [73-75]. Rituximab was part of the induction regimen in 2 of the trials, but not in the third; it has been shown that previous rituximab treatment with resulting B cell ablation does not affect the ability of an anti-Id vaccine to elicit cellular responses. Although these studies are different in terms of therapeutic schedule, subset of patients and vaccine production technique, they have shown an improvement of PFS (progression free survival) or DFS (disease free survival) in the group of patients mounting an anti Id-specific immune response. However, after several years, clinical results about tumor-specific protein vaccine strategy in the context of NHL appear still unsatisfactory compared to the great outcome of monoclonal antibodies.

\section{Discussion}

Albeit the rationale behind the development of antitumor peptide vaccines is solid and hundreds of preclinical studies have validated their role as potential mediators of an antitumor response in vivo, clinical results have been disappointing in the majority of trials. One critical issue may be the clinical setting in which antitumor peptide vaccines are applied. Tumor debulking through conventional treatment (i.e., chemotherapy, radiotherapy, surgery) is a necessary step before vaccination because advanced tumor load is associated with redundant immunosuppression. Thus, the reduction of tumor burden may greatly diminish the immunosuppressive mechanisms sometimes associated with tumor growth to allow more vigorous expansion of antitumor effectors. Considering this aspect, hematological malignancies offer particular characteristics that should make them an ideal target of vaccine-based therapeutic interventions. In fact, in the vast majority of 
patients, chemotherapy produces an effective tumor debulking and a minimal residual disease state in the context of which immune therapy may be inserted.

After determining the optimal setting of application of an antitumor vaccine, the subsequent aspect to take into consideration, is the clinical response and its evaluation. The ultimate goal of any treatment is to cure a disease. When such achievement is not promptly accomplished, surrogate end points are used that may provide a conceptual bridge between the intervention and its target. In the field of immune therapy, this concept is extremely appropriate, because cancer vaccines constitute a unique therapeutic modality in that they initiate a dynamic process involving the host's immune response. Consequently, a repeated dose of peptide vaccinations over months may be required before patient's clinical benefit is observed and there most likely will be a "dynamic balance" between the induction and maintenance of host immune response elements to the vaccinations vs host/tumor factors that have the potential to diminish those responses. Thus, "patient response" in the sense of disease stabilization and prolonged survival may be more appropriate to monitor than strictly "tumor response". This can be obtained, for example, in the form of enhanced patient benefit to subsequent therapies following vaccine therapy.

Another aspect that is crucial but yet controversial is the immunological response to the peptide vaccine that is often considered a surrogate of a clinical response. Based on the results of several clinical studies, statistical correlations do not always exist between antigen-specific immune responses to vaccine and patient benefit. These findings may be confounded by several phenomena: (i) the majority of studies have examined antigen-specific CD4+ or CD8+ T cells only in blood, which may not always correlate with their presence in the bone marrow or in the other tumor sites; (ii) only a few studies have monitored the avidity of antigen-specific $\mathrm{T}$ cells against tumor [76]; (iii) rarely is evaluated the presence of $\mathrm{T}$ cells directed against other tumor-associated antigens as a result of the initial tumor-cell disruption by peptide vaccineinduced $T$ cells [77]. In conclusion, the era of antitumor vaccine (and particularly tumor-derived peptide vaccines) is not surely at the end, but it will be challenging for tumor immunologists to find a role for this still fascinating approach, while more and more new target molecules will be available to treat hematologic malignancies.

\section{References}

1. Horowitz MM, Gale RP, Sondel PM, Goldman JM, Kersey J, Kolb HJ, et al. Graft-versus-leukemia reactions after bone marrow transplantation. Blood. 1990;75:555-62.
2. Collins RH Jr, Shpilberg O, Drobyski WR, Porter DL, Giralt S, Champlin R, et al. Donor leukocyte infusions in 140 patients with relapsed malignancy after allogeneic bone marrow transplantation. J Clin Oncol. 1997;15:433-44.

3. Tricot G, Vesole DH, Jagannath S, Hilton J, Munshi N, Barlogie B. Graft-versus-myeloma effect: proof of principle. Blood. 1996;87:1196-8.

4. Pardoll DM. Cancer vaccines. Nat Med. 1998;4:525-31.

5. van der Bruggen $P$, Traversari C, Chomez P, Lurquin C, De Plaen E, Van der Eynde B, et al. A gene encoding an antigen recognized by cytolytic $\mathrm{T}$ lymphocytes on a human melanoma. Science. 1991;254:1643-7.

6. Novellino L, Castelli C, Parmiani G. A listing of human tumor antigens recognized by $T$ cells: March 2004 update. Cancer Immunol Immunother. 2005;54:187-207.

7. Traversari C, van der Bruggen $P$, Luescher IF, Lurquin C, Chomez P, Van Pel A, et al. A nonapeptide encoded by human gene MAGE-1 is recognized on HLA-A1 by cytolytic T lymphocytes directed against tumor antigen MZ2-E. J Exp Med. 1992;176: 1453-7.

8. van Baren N, Brasseur F, Godelaine D, Hames G, Ferrant A, Lehmann $\mathrm{F}$, et al. Genes encoding tumor-specific antigens are expressed in human myeloma cells. Blood. 1999;94:1156-64.

9. Greiner J, Ringhoffer M, Simikopinko O, Szmaragowska A, Huebsch S, Maurer U, et al. Simultaneous expression of different immunogenic antigens in acute myeloid leukemia. Exp Hematol. 2000;28:1413-22.

10. Molldrem J, Dermime S, Parker K, Jiang YZ, Mavroudis D, Hensel N, et al. Targeted T-cell therapy for human leukemia: cytotoxic $\mathrm{T}$ lymphocytes specific for a peptide derived from proteinase 3 preferentially lyse human myeloid leukemia cells. Blood. 1996;88:2450-7.

11. Bergmann L, Maurer U, Weidmann E. Wilms tumor gene expression in acute myeloid leukemias. Leuk Lymphoma. 1997;25:435-43.

12. Takahashi T, Makiguchi Y, Hinoda Y, Kakiuchi H, Nakagawa N, Imai $\mathrm{K}$, et al. Expression of MUC1 on myeloma cells and induction of HLA-unrestricted CTL against MUC1 from a multiple myeloma patient. J Immunol. 1994;153:2102-9.

13. Bocchia M, Wentworth PA, Southwood S, Sidney J, McGraw K, Scheinberg DA, et al. Specific binding of leukemia oncogene fusion protein peptides to HLA class I molecules. Blood. 1995;85:2680-4.

14. Disis ML, Cheever MA. Oncogenic proteins as tumor antigens. Curr Opin Immunol. 1996;8:637-42.

15. Bendandi M. Idiotype vaccines for lymphoma: proof of principles and clinical trial failures. Nat Rev Cancer. 2009;9:675-81.

16. Stevenson G, Elliott TE, Stevenson FK. Idiotypic determinants on the surface immunoglobulin of neoplastic lymphocytes: a therapeutic target. Fed Proc. 1977;36:2268-71.

17. Unanue ER, Cerottini JC. Antigen presentation. FASEB J. 1989;3:2496-502.

18. Kirkwood JM, Strawderman MH, Ernstoff MS, Smith TJ, Borden EC, Blum RH. Interferon alpha-2b adjuvant therapy of high risk resected cutaneous melanoma: the Eastern Cooperative Oncology Group Trial EST 1684. J Clin Oncol. 1996;14:7-17.

19. Rosemberg SA, Yang JC, Topalian SL, Schwartzentruber DJ, Weber JS, Parkinson DR, et al. Treatment of 283 consecutive patients with metastatic melanoma or renal cell cancer using high dose bolus interleukin-2. JAMA. 1994;271:907-13.

20. de Visser KE, Cordaro TA, Kessels HW, Tirion FH, Schumacher TN, Kruisbeek AM. Low avidity self-specific T cells display a pronounced expansion defect that can be overcome by altered peptide-ligands. J Immunol. 2001;167:3818-28.

21. Toes RE, Offringa R, Blom RJ, Melief CJ, Kast WM. Peptide vaccination can lead to enhanced tumor growth through specific 
T-cell tolerance induction. Proc Natl Acad Sci USA. 1996;93: 7855-60.

22. Srinivasan M, Domanico SZ, Kaumaya PT, Pierce SK. Peptides of 23 residues or greater are required to stimulate a high affinity class II-restricted T cell response. Eur J Immunol. 1993;23: 1011-6.

23. Janssen EM, Droin NM, Lemmens EE, Pinkoski MJ, Bensinger SJ, Ehst BD, et al. CD4 $+\mathrm{T}$ cell help helps control CD8 $+\mathrm{T}$ cell memory via TRAIL-mediated activation-induced cell death. Nature. 2010;434:88-93.

24. Nishikawa H, Jager E, Ritter G, Old LJ, Gnjatic S. $\mathrm{CD} 4+\mathrm{CD} 25+$ regulatory $\mathrm{T}$ cells control the induction of antigen-specific $\mathrm{CD} 4+$ helper $\mathrm{T}$ cell responses in cancer patients. Blood. 2005;106:1008-11.

25. Ichihara F, Kono K, Takahashi A, Kawaida H, Sugai H, Fujii H. Increased populations of regulatory $\mathrm{T}$ cells in peripheral blood and tumor-infiltrating lymphocytes in patients with gastric and esophageal cancers. Clin Cancer Res. 2003;9:4404-8.

26. Sasada T, Kimura M, Yoshida Y, Kanai M, Takabayashi A. $\mathrm{CD} 4+\mathrm{CD} 25+$ regulatory $\mathrm{T}$ cells in patients with gastrointestinal malignancies: possible involvement of regulatory $\mathrm{T}$ cells in disease progression. Cancer. 2003;98:1089-99.

27. Emadi A, Jones RJ, Brodsky RA. Cyclophosphamide and cancer: golden anniversary. Nat Rev Clin Oncol. 2009;6:638-47.

28. Mahnke K, Schonfeld K, Fondel S, Ring S, Karakhanova S, Wiedemeyer $\mathrm{K}$, et al. Depletion of CD4 + CD25 + human regulatory $\mathrm{T}$ cells in vivo: kinetics of Treg depletion and alterations in immune functions in vivo and in vitro. Int $\mathrm{J}$ Cancer. 2007;120:2723-33.

29. Rech AJ, Vonderheide RH. Clinical use of anti-CD25 antibody daclizumab to enhance immune responses to tumor antigen vaccination by targeting regulatory T cells. Ann NY Acad Sci. 2009;1174:99-106.

30. Fraser CK, Diener KR, Brown MP, Hayball JD. Improving vaccines by incorporating immunological coadjuvants. Exp Rev Vaccines. 2007;6:559-78.

31. Bendandi M, Gocke CD, Kobrin CB, Benko FA, Sternas LA, Pennington $\mathrm{R}$, et al. Complete molecular remissions induced by patient-specific vaccination plus granulocyte-monocyte colonystimulating factor against lymphoma. Nat Med. 1999;5:1171-7.

32. Kusmartsev S, Gabrilovich DI. Immature myeloid cells and cancer-associated immune suppression. Cancer Immunol Immunother. 2002;51:293-8.

33. Parmiani G, Castelli C, Pilla L, Santinami M, Colombo P, Rivoltini L. Opposite immune functions of GM-CSF administered as vaccine adjuvant in cancer patients. Ann Oncol. 2007; 18:226-32.

34. Aggarwal S, van de Loosdrecht AA, Alhan C, Ossenkoppele GJ, Westers TM, Bontkes HJ. Role of immune responses in the pathogenesis of low-risk MDS and high-risk MDS: implications for immunotherapy. Br J Haematol. 2011;153:568-81.

35. Qazilbash MH, Wieder ED, Thall PF, Wang X, Rios RL, Lu S, et al. PR1 peptide vaccine-induced immune response is associated with better event-free survival in patients with myeloid leukemia. [Abstract]. Blood. 2007;110:283.

36. Greiner J, Schmitt A, Giannopoulos K, Rojewski MT, Götz M, Funk I, et al. High-dose RHAMM-R3 peptide vaccination for patients with acute myeloid leukemia, myelodysplastic syndrome and multiple myeloma. Haematologica. 2010;95:1191-7.

37. Oka Y, Tsuboi A, Taguchi T, Osaki T, Kyo T, Nakajima H, et al. Induction of WT1 (Wilms' tumor gene)-specific cytotoxic T lymphocytes by WT1 peptide vaccine and the resultant cancer regression. Proc Natl Acad Sci USA. 2004;101:13885-90.

38. Keilholz U, Letsch A, Busse A, Asemissen AM, Bauer S, Blau IW, et al. A clinical and immunologic phase 2 trial of Wilms tumor gene product 1 (WT1) peptide vaccination in patients with AML and MDS. Blood. 2009;113:6541-8.

39. Maslak PG, Dao T, Krug LM, Chanel S, Korontsvit T, Zakhaleva $\mathrm{V}$, et al. Vaccination with synthetic analog peptides derived from WT1 oncoprotein induces T-cell responses in patients with complete remission from acute myeloid leukemia. Blood. 2010;116:171-9.

40. Sugiyama H, Tsuboi A, Oka Y, Kio T, Katayama Y, Olga E, et al. Long-term WT1 peptide vaccination over 7 years for 3 AML patients with molecular relapse. [Abstract]. Blood. 2010;116: 3295

41. Rezvani K, Yong AS, Mielke S, Savani BN, Musse L, Superata J, et al. Leukemia-associated antigen specific T-cell responses following combined PR1 and WT1 peptide vaccination in patients with myeloid malignancies. Blood. 2008;111:236-42.

42. Rezvani K, Yong AS, Mielke S, Jafarpour B, Savani BN, Le RQ, et al. Repeated PR1 and WT1 peptide vaccination in Montanideadjuvant fails to induce sustained high-avidity, epitope-specific CD8+ T cells in myeloid malignancies. Haematologica. 2011;96: 432-40.

43. Sugiyama H. Wilms' tumor gene WT1: its oncogenic function and clinical application. Int J Hematol. 2001;73:177-87.

44. Elisseeva OA, Oka Y, Tsuboi A, Ogata K, Wu F, Kim EH, et al. Humoral immune responses against Wilms tumor gene WT1 product in patients with hematopoietic malignancies. Blood. 2002;99:3272-9.

45. Ochsenreither S, Fusi A, Geikowski A, Stather D, Busse A, Stroux A, et al. Wilms' tumor protein 1 (WT1) peptide vaccination in AML patients: predominant TCR CDR3 $\beta$ sequence associated with remission in one patient is detectable in other vaccinated patients. Cancer Immunol Immunother. 2012;61:313-22.

46. Padua RA, Chomienne C. Use of animal models for the treatment of leukemias: efficacy of DNA vaccination combined with ATRA. Discov Med. 2004;4:41-4.

47. Bocchia M, Ippoliti M, Gozzetti A, Abruzzese E, Calabrese S, Amabile M, et al. CD34+/Ph+cells are still detectable in chronic myeloid leukaemia patients with sustained and prolonged complete cytogenetic remission during treatment with imatinib mesylate. Leukemia. 2007;22:426-8.

48. Bocchia M, Korontsvit T, Xu Q, Mackinnon S, Yang SY, Sette A, et al. Specific human cellular immunity to bcr-abl oncogene derived peptides. Blood. 1996;87:3587-92.

49. Clark RE, Dodi IA, Hill SC, Lill JR, Aubert G, Macintyre AR, et al. Direct evidence that leukemic cells present HLA-associated immunogenic peptides derived from the BCR-ABL b3a2 fusion protein. Blood. 2001;98:2887-93.

50. Pinilla-Ibarz J, Cathcart K, Korontsvit T, Soignet S, Bocchia M, Caggiano J, et al. Vaccination of patients with chronic myelogenous leukemia with bcr-abl oncogene breakpoint fusion peptides generates specific immune responses. Blood. 2000;95:1781-7.

51. Cathcart K, Pinilla-Ibarz J, Korontsvit T, Schwartz J, Zakhaleva $\mathrm{V}$, Papadopoulos EB, et al. A multivalent bcr-abl fusion peptide vaccination trial in patients with chronic myeloid leukemia. Blood. 2004;103:1037-42.

52. Bocchia M, Gentili S, Abruzzese E, Fanelli A, Iuliano F, Tabilio A, et al. Effect of a p210 multipeptide vaccine associated with imatinib or interferon in patients with chronic myeloid leukaemia and persistent residual disease: a multicentre observational trial. Lancet. 2005;365:657-62.

53. Rojas JM, Knight K, Wang L, Clark RE. Clinical evaluation of BCR-ABL peptide immunization in chronic myeloid leukaemia: results of the EPIC study. Leukemia. 2007;21:2287-95.

54. Maslak PG, Dao T, Gomez M, Chanel S, Packin J, Korontsvit T, Zakhaleva $\mathrm{V}$, et al. A pilot vaccination trial of synthetic analog 
peptides derived from the BCR-ABL breakpoints in CML patients with minimal disease. Leukemia. 2008;22:1613-6.

55. Jain N, Reuben JM, Kantarjian H, Li C, Gao H, Lee BN, Cohen EN, et al. Synthetic tumor-specific breakpoint peptide vaccine in patients with chronic myeloid leukemia and minimal residual disease: a phase 2 trial. Cancer. 2009;115:3924-34.

56. Bocchia M, Defina M, Ippoliti M, Amabile M, Breccia M, Iuliano $\mathrm{F}$, et al. BCR-ABL derived peptide vaccine in chronic myeloid leukemia patients with molecular minimal residual disease during imatinib: interim analysis of a phase 2 multicenter GIMEMA CML working party trial [Abstract]. Blood. 2009;114:648.

57. Deinenger M, O'Brien S, Guilhot F, Goldman JM, Hochhaus A, Hughes TP, et al. International randomized study of Interferon vs STI571 (IRIS) 8-year follow up: sustained survival and low risk for progression on events in patients with newly diagnosed chronic myeloid leukemia in chronic phase (CML-CP) treated with imatinib. [Abstract]. Blood. 2009;114:1126.

58. Brauer KM, Werth D, von Schwarzenberg K, Bringmann A, Kanz L, Grünebach F, et al. BCR-ABL activity is critical for the immunogenicity of chronic myelogenous leukemia cells. Cancer Res. 2007;67:5489-97.

59. Vonka V. Immunotherapy of chronic myeloid leukemia: present state and future prospects. Immunotherapy. 2010;2:227-41.

60. Schetelig J, Kiani A, Schmitz M, Ehninger G, Bornhäuser M. T cell-mediated graft-versus-leukemia reactions after allogeneic stem cell transplantation. Cancer Immunol Immunother. 2005;54:1043-58.

61. Yi Q, Osterborg A, Bergenbrant S, Mellstedt H, Holm G, Lefvert AK. Idiotype-reactive T-cell subsets and tumor load in monoclonal gammopathies. Blood. 1995;86:3043-9.

62. Osterborg A, Yi Q, Henriksson L, Fagerberg J, Bergenbrant S, Jeddi-Tehrani $\mathbf{M}$, et al. Idiotype immunization combined with granulocyte-macrophage colony-stimulating factor in myeloma patients induced type I, major histocompatibility complexrestricted, CD8- and CD4-specific T-cell responses. Blood. 1998;91:2459-66.

63. Rasmussen T, Hansson L, Osterborg A, Johnsen HE, Mellstedt H. Idiotype vaccination in multiple myeloma induced a reduction of circulating clonal tumor B cells. Blood. 2003;11:4607-10.

64. Coscia M, Mariani S, Battaglio S, Di Bello C, Fiore F, Foglietta $\mathrm{M}$, et al. Long-term follow-up of idiotype vaccination in human myeloma as a maintenance therapy after high-dose chemotherapy. Leukemia. 2004;1:139-45.

65. Foglietta M, Neelapu SS, Kwak LW, Jiang Y, Nattamai D, Lee ST, et al. Neoantigen and tumor antigen-specific immunity transferred from immunized donors is detectable early after allogeneic transplantation in myeloma patients. Bone Marrow Transplant. 2013;48:269-77.

66. Szmania S, Tricot G, van Rhee F. NY-ESO-1 immunotherapy for multiple myeloma. Leukemia Lymphoma. 2006;47:2037-48.
67. Kuball J, de Boer K, Wagner E, Wattad M, Antunes E, Weeratna RD, et al. Pitfalls of vaccinations with WT1-, Proteinase3- and MUC1-derived peptides in combination with MontanideISA51 and CpG7909. Cancer Immunol Immunother. 2011;60:161-71.

68. Qian J, Zheng Y, Zheng C, Wang L, Qin H, Hong S, et al. Active vaccination with Dickkopf-1 induces protective and therapeutic antitumor immunity in murine multiple myeloma. Blood. 2012;119:161-9.

69. Biernacki MA, Tai YT, Zhang GL, Alonso A, Zhang W, Prabhala $\mathrm{R}$, et al. Novel myeloma-associated antigens revealed in the context of syngeneic hematopoietic stem cell transplantation. Blood. 2012;119:3142-50.

70. Kang YJ, Zeng W, Song W, Reinhold B, Choi J, Brusic V, et al. Identification of human leucocyte antigen (HLA)-A*0201restricted cytotoxic $\mathrm{T}$ lymphocyte epitopes derived from HLA$\mathrm{DO} \beta$ as a novel target for multiple myeloma. Br J Haematol. 2013;163:343-51.

71. Giannopoulos K, Własiuk P, Dmoszyńska A, Roliński J, Schmitt $M$. Peptide vaccination induces profound changes in the immune system in patients with B-cell chronic lymphocytic leukemia. Folia Histochem Cytobiol. 2011;49:161-7.

72. Dubensky TW Jr, Reed SG. Adjuvants for cancer vaccines. Semin Immunol. 2010;22:155-61.

73. Schuster SJ, Neelapu SS, Gause BL, Janik JE, Muggia FM, Gockerman JP, et al. Vaccination with patient-specific tumorderived antigen in first remission improves disease-free survival in follicular lymphoma. Clin Oncol. 2011;29:2787-94.

74. Levy R, Robertson MJ, Ganjoo K, Leonard J, Vose J, Denney DJ. Results of a Phase 3 trial evaluating safety and efficacy of specific immunotherapy, recombinant idiotype (Id) conjugated to KLH (Id-KLH) with GM-CSF, compared with non-specific immunotherapy, KLH with GM-CSF, in patients with follicular nonHodgkin's lymphoma (fNHL). AACR Meeting Abstracts. 2008;LB-204.

75. Freedman A, Neelapu SS, Nichols C, Robertson MJ, Djulbegovic B, Winter JN, et al. Placebo-controlled phase III trial of patientspecific immunotherapy with mitumprotimut-T and granulocytemacrophage colony-stimulating factor after rituximab in patients with follicular lymphoma. J Clin Oncol. 2009;27:3036-43.

76. Rubio V, Stuge TB, Singh N, Betts MR, Weber JS, Roederer M, et al. Ex vivo identification, isolation and analysis of tumorcytolytic T cells. Nat Med. 2003;9:1377-82.

77. Chakraborty M, Abrams SI, Coleman CN, Camphausen K, Schlom J, Hodge JW. External beam radiation of tumors alters phenotype of tumor cells to render them susceptible to vaccinemediated T-cell killing. Cancer Res. 2004;64:4328-37. 